\title{
elyra
}

\section{Regras para uma competição no deserto (romance)}

\section{Carlos Augusto Lima}

7.

Simples: divida o grupo em duas equipes. Depois, tranque cada equipe em dois quartos. A seguir, perca as chaves.

9.

Forma-se um círculo de cadeiras, com um número a menos que o número de participantes. A seguir, ordena-se que todos tratem de andar em círculo, ao redor do círculo de cadeiras. Todos acompanham o ritmo da música estridente. A música jamais cessa. Os participantes não param jamais. O limite é a exaustão e a queda. Não há vencedores.

10.

Antes de iniciar a partida, os competidores devem estar preparados para se auto imolar e arrancar com destreza cada um de seus olhos. Os globos oculares são jogados pela areia do deserto, num gesto sem fim, por competidores tolos, banidos com convívio dos homens de bem.

18.

O jogo consiste em desenhar uma sequência de quadrados no chão para que se pule dentro deles. Primeiro um só, onde se deve apoiar um único pé. Depois dois quadrados, onde 
colocam-se os dois pés. Depois um só, depois dois e assim sucessivamente, repetindo e repetindo e repetindo, ad infinitum. Algumas culturas afirmavam que, só assim, se poderia chegar ao que chamavam: "céu". Para nós, no entanto, isso é algo improvável.

20.

Deve-se formar um círculo com todos os participantes sentados. Alguém inicia falando discretamente uma palavra, em alguma língua morta, no ouvido do colega do lado, que deve traduzir e dizer, também numa outra língua morta, para o colega do lado, e assim seguidamente e de maneira ininterrupta. Não se deve parar nunca de falar.

47.

Ao ouvir o sinal, cada participante deve correr o mais rápido possível. Não há onde chegar.

48.

É simples: nós escolhemos uma pessoa entre nós e ela poderá atirar no primeiro que se mexer.

63.

Eu vou contar até 3. Aí, então, nada acontece.

88.

Uma pessoa lança a bola para o alto e grita o nome de alguém q um dos participantes está tentando esquecer.

91.

Vendam-se os olhos da equipe adversária e eles tentam não cair no abismo.

99.

O participante escolhido deverá correr para tentar pegar os demais. Ele estará com as mãos e os pés atados. 
102.

Duas linhas no chão são traçadas. Uma de partida, outra de chegada. Divide-se os participantes em pares. Um corredor de cada dupla apoia-se sobre o corpo do outro, amordaça a boca e perfura os olhos do companheiro, prende-lhe a respiração. A queda é iminente. Vence a dupla que primeiro cruzar a linha de chegada.

\section{1.}

A forma ideal é a de lançar uma das pedras para o alto e, antes que a mesma caia no chão, recolher de imediato as outras. Joga-se melhor sob gravidade zero.

\section{1.}

Segundo regras internacionais, os participantes são divididos em duas equipes, cada qual com oito componentes. Os competidores ficam dispostos em linha reta, cada linha de frente para a outra. Entre os grupos existe uma marca central. O objetivo é puxar o grupo adversário até que o primeiro da fila oposta atravesse a tal marca. A disputa se dá puxando um extenso fio de cabelo que não pode ser partido em nenhum lugar, nenhuma parte, em hipótese alguma. Nunca houve vencedores.

\section{7.}

O nome desta brincadeira é: estátua. Devo avisar que nenhum participante voltou a sua forma humana, desde que a inventaram.

\section{9.}

Brincam um mestre e vários participantes. O mestre entabula um diálogo introdutório e cheio de perguntas desconexas, que não são respondidas pelos participantes. A seguir e ao sinal, o mestre pede que os participantes encontrem: 1) uma agulha perdida num palheiro; 2) um elefante que já fora transpassado pelo buraco de uma agulha; 3) o endereço de uma casa cujos moradores nunca perderam um ente querido. Ganha quem achar. 
165.

Há uma brincadeira, registrada em várias culturas, que consiste em passar discretamente, com as mãos em forma de concha, um montante de pequenos objetos tais como cacos de vidro, pregos, giletes, tachas, cravos, pedregulhos em brasa, para as mãos do colega do lado, também em conchas. A passagem é ininterrupta, podendo durar horas, talvez dias, semanas. Ganha quem não esboçar nenhuma manifestação de dor.

170.

Formam-se duplas e os participantes colocam-se frente a frente. Deve-se olhar um para o outro sem fazer movimento, sem alterar a fisionomia e o riso não é permitido. Ganha a dupla que, na profundidade e vasculhamento do olhar, cair primeiro em prantos.

199.

Um jogo que é dos mais complexos que se tem registro. É escolhido um participante e a este é dado um balão de gás hélio. 0 participante deve soltar o balão ao mesmo tempo em que grita o nome de um dos participantes. Este deve tentar pegar o balão e, de imediato, fazer com que os outros participantes estejam fixados em seus lugares, imóveis, assim que for ordenado. Até agora, nenhum balão foi apanhado, os demais participantes não pararam de correr e uma pessoa, umas tantas vezes, é vista com olhar perdido para o céu, para espanto de alguns.

199.

Vamos brincar de esconde-esconde? É assim: você se esconde. E eu, também. 